\title{
Has Prey Availability for Arctic Birds Advanced with Climate Change? Hindcasting the Abundance of Tundra Arthropods Using Weather and Seasonal Variation
}

\author{
INGRID TULP ${ }^{1}$ and HANS SCHEKKERMAN ${ }^{2}$
}

\author{
(Received 27 September 2006; accepted in revised form 28 June 2007)
}

\begin{abstract}
Of all climatic zones on earth, Arctic areas have experienced the greatest climate change in recent decades. Predicted changes, including a continuing rise in temperature and precipitation and a reduction in snow cover, are expected to have a large impact on Arctic life. Large numbers of birds breed on the Arctic tundra, and many of these, such as shorebirds and passerines, feed on arthropods. Their chicks depend on a short insect population outburst characteristic of Arctic areas. To predict the consequences of climate change for reproduction in these birds, insight into arthropod phenology is essential. We investigated weather-related and seasonal patterns in abundance of surface-active arthropods during four years in the tundra of NW Taimyr, Siberia. The resulting statistical models were used to hindcast arthropod abundance on the basis of a 33-year weather dataset collected in the same area. Daily insect abundance was correlated closely with date, temperature, and, in some years, with wind and precipitation. An additional correlation with the number of degree-days accumulated after 1 June suggests that the pool of potential arthropod recruits is depleted in the course of the summer. The amplitude of short-term, weather-induced variation was as large as that of the seasonal variation. The hindcasted dates of peak arthropod abundance advanced during the study period, occurring seven days earlier in 2003 than in 1973. The timing of the period during which birds have a reasonable probability of finding enough food to grow has changed as well, with the highest probabilities now occurring at earlier dates. At the same time, the overall length of the period with probabilities of finding enough food has remained unchanged. The result is an advancement of the optimal breeding date for breeding birds. To take advantage of the new optimal breeding time, Arctic shorebirds and passerines must advance the start of breeding, and this change could affect the entire migratory schedule. Because our analyses are based on a single site, we cannot conclude that this is a general pattern for the entire Arctic. To investigate the generality of this pattern, our approach should be applied at other sites too.
\end{abstract}

Key words: climate change, arthropods, Siberia, timing of breeding, phenology, Arctic birds

RÉSUMÉ. De toutes les zones climatiques de la Terre, ce sont les régions de l'Arctique qui ont enregistré le plus grand changement climatique au cours des dernières décennies. Les changements prévus, qui comprennent notamment l'augmentation continue des températures et des précipitations de même que la diminution de la couverture de neige, devraient avoir de grandes incidences sur la vie de l'Arctique. De grandes quantités d'oiseaux se reproduisent sur la toundra de l'Arctique, et beaucoup d'entre eux, tels que les oiseaux de rivage et les passériformes, se nourrissent d'arthropodes. Leurs oisillons dépendent d'une courte affluence de population d'insectes, ce qui est caractéristique des régions arctiques. Afin de prévoir les conséquences du changement climatique sur la reproduction de ces oiseaux, il faut absolument se familiariser avec la phénologie des arthropodes. Nous avons examiné les modèles météorologiques et saisonniers dans les cas d'abondance d'arthropodes actifs à la surface pendant une période de quatre ans dans la toundra du nord-ouest de Taimyr, en Sibérie. Les modèles statistiques qui en ont découlé ont permis de faire des simulations rétrospectives de l'abondance des arthropodes en fonction d'un ensemble de données météorologiques échelonnées sur 33 ans, données qui avaient été recueillies dans cette même région. L'abondance des insectes au quotidien a été étroitement corrélée avec la date, la température et, pour certaines années, le vent et les précipitations. Une autre corrélation avec le nombre

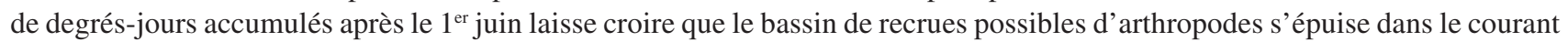
de l'été. L'amplitude de la variation à court terme attribuable aux conditions atmosphériques était aussi considérable que la variation saisonnière. Les dates de simulation rétrospective des périodes d'abondance de pointe chez les arthropodes ont avancé pendant la période visée par l'étude, se manifestant ainsi sept jours plus tôt en 2003 qu'en 1973. La répartition dans le temps de la période pendant laquelle les oiseaux ont une probabilité raisonnable de trouver suffisamment de nourriture pour grandir a également changé, les probabilités les plus fortes se manifestant maintenant plus tôt. Pour sa part, la durée générale de la période comportant des probabilités de trouver suffisamment de nourriture est demeurée inchangée. Cela donne donc lieu à l'avancement de la date optimale de reproduction pour les oiseaux nicheurs. Pour profiter de la nouvelle période de reproduction optimale, les oiseaux de rivage de l'Arctique et les passériformes doivent faire avancer le début de la période de reproduction, ce qui veut dire que ce changement pourrait avoir des effets sur tout le calendrier de migration. Puisque nos analyses ne sont fondées que sur un seul emplacement, nous ne pouvons pas en conclure qu'il s'agit là d'un modèle général pour l'Arctique dans son ensemble. Afin de déterminer la généralité de ce modèle, notre démarche devrait également être appliquée à d'autres emplacements.

\footnotetext{
${ }^{1}$ Institute for Marine Resources and Ecosystem Studies, P.O. Box 68, 1970 AB IJmuiden, The Netherlands; ingrid.tulp@wur.nl

${ }^{2}$ Dutch Centre for Avian Migration and Demography, NIOO-KNAW, P.O. Box 40, 6666 ZG Heteren, The Netherlands;

h.schekkerman@nioo.knaw.nl

(C) The Arctic Institute of North America
} 
PREY AVAILABILITY FOR ARCTIC BIRDS • 49

Mots clés : changement climatique, arthropodes, Sibérie, choix du moment de la reproduction, phénologie, oiseaux de l'Arctique

Traduit pour la revue Arctic par Nicole Giguère.

\section{INTRODUCTION}

Global warming is causing the permanent ice cover at the North Pole to melt faster than was previously expected (McBean, 2005; Meehl et al., 2005). According to the Arctic Climate Impact Assessment (McBean, 2005), seaice cover has decreased by $15 \%$ to $20 \%$ in the past 30 years. Arctic tundra forms the northern fringes of the continents bordering the Arctic seas. Given the great influence of sea ice on the climate in Arctic areas, Arctic tundra is one of the terrestrial ecosystems likely to be highly vulnerable to climate change. The annual average temperature has increased at almost twice the rate in the Arctic compared to that in the rest of the world (Callaghan et al., 2005). Generally, vegetation types, snow, and weather regimes are expected to show extensive changes, and these changes will be more pronounced in the Arctic than at temperate latitudes (Callaghan et al., 2005). Climate models predict that temperatures will increase (more so in winter than in summer), precipitation will increase, and the duration of snow cover will decrease (Kattsov and Källen, 2005; McBean, 2005).

Arctic tundra areas are the breeding grounds for a great number of migratory birds that spend the boreal winter in temperate or tropical zones. The long daylight period, sufficient food availability, and possibly a general scarcity of parasites, pathogens, and predators, allow their offspring to survive and grow rapidly (Carey, 1986; Helmers and Gratto-Trevor, 1996; Piersma, 1997; Lepage et al., 1998; Andreev, 1999; Schekkerman et al., 2003). Birds that feed on terrestrial invertebrates, such as shorebirds and passerines (Custer and Pitelka, 1978), make up a significant part of Arctic landbird communities (Chernov, 1985; Troy, 1996). The adults of several of these species and the young of most depend mainly on surface-active arthropods for food. Shorebird chicks feed for themselves from their first day of life onward, taking arthropods from the tundra surface while walking around attended by one or two parents. Passerine chicks remain in the nest for at least the first part of their pre-fledging period and are fed arthropod prey by the parents.

In the Arctic, arthropods are active and lay their eggs in the summer and spend the winter as eggs, larvae, (pre)pupae, or in some cases as inactive adults (Chernov, 1978; Danks, 1981a, b; Downes, 1981). The latter two strategies in particular can result in a highly synchronized emergence of adults in the summer. Development is controlled by cumulative temperature or temperature thresholds in many species (Danks, 1999). The first arthropods emerge at the onset of temperature rise and snowmelt. After emergence, adult insects of many species devote their time mainly to reproduction and die shortly afterwards. This results in a characteristic short burst of adult arthropod abundance (MacLean and Pitelka, 1971).

The predicted increase in winter temperature is likely to result in an increase in alternating periods of melting and freezing in some areas (Callaghan et al., 2005). These freeze-thaw cycles may reduce the winter survival of insects, either by ice-crust formation leading to anoxic conditions or by loss of cold-hardiness during an early melt period followed by further freezing (Hodkinson et al., 1998; Sinclair et al., 2003; Hodkinson, 2005; Turnock and Fields, 2005). With increasing summer temperatures, seasonal patterns of arthropod emergence may be altered or disrupted, especially in species with highly seasonal life cycles (Hodkinson et al., 1998). Changes in the phenology of summer emergence may affect the life cycles of the arthropods themselves (in either positive or negative ways), but they will also affect the seasonal pattern of food availability for birds (and other invertebrate predators), and possibly the optimal timing for breeding for these species. Such an effect is expected if food abundance limits the period in which successful breeding is possible. Many investigators have pointed out the synchrony of hatching dates of Arctic shorebirds and passerines with the local midsummer peak in insect emergence (Hurd and Pitelka, 1954; Holmes, 1966a, b; Schekkerman et al., 1998, 2003; Pearce-Higgins and Yalden, 2004). Also, Schekkerman et al. (2003) have shown that growth rate of shorebird chicks is correlated with shortterm variation in surface arthropod availability, and this growth rate translates into chick survival. Similar correlations between arthropod abundance and chick growth have also been demonstrated in passerines (Hart et al., 2006), although this relationship has not yet been investigated in Arctic areas.

Arctic birds may have difficulties adapting to changes in the timing of arthropod availability if they face constraints (e.g., migration, snowmelt) or use timing cues that do not match changes in the timing of food availability (Both et al., 2005). Also, migrating birds may be unable to predict at southerly latitudes (characterized by relatively small climatic change) the start of the season thousands of kilometres north. If birds cannot respond to changes in the timing of prey abundance, this may affect their breeding success and population size (Both et al., 2006). The seasonal pattern of arthropod surface activity is thus a yardstick against which to evaluate changes in phenology of animal groups that depend on them (Visser and Both, 2005).

In this paper, we describe the variability in arthropod abundance on the tundra surface during summer in relation to date and weather conditions, on both short (withinseason) and long (between-year) time scales, on the basis of four years of field data from one site in Arctic Siberia. From a "food for birds" perspective, short-term relationships 
between arthropod abundance and weather are as important as long-term seasonal patterns, because they greatly affect the predictability of food abundance. Capitalizing on the tight relationships observed between weather, date, and arthropod abundance, we use the statistical model derived from the field data to hindcast arthropod abundance, using a 33-year weather dataset collected in the same area. The hindcasted yearly abundance curves are then used to investigate interannual variability and time trends that may have occurred in relation to climate change.

\section{MATERIAL AND METHODS}

\section{Study Site}

Data were collected during four summers (1996, 2000 02) at Medusa Bay, $18 \mathrm{~km}$ south of Dikson on the Taimyr Peninsula, Siberia $\left(73^{\circ} 20^{\prime} \mathrm{N} 80^{\circ} 30^{\prime} \mathrm{E}\right)$. Field seasons ran from early June to mid-August. (The 1996 expedition covered only the period 21 June-21 July and will be used for a subset of the analyses only.) The opening date of the field period in the other years was planned so that the observations of arthropod abundance started on the date when the tundra emerged from under the snow. The study area was situated in the Arctic tundra (cf. Chernov, 1985). Vegetation consisted of mosses, lichens, grasses and sedges, dwarf willows Salix polaris, and various herbs generally not higher than $20 \mathrm{~cm}$, with a substantial proportion (up to 20\%) of bare soil surface. Patches of bare soil consisted of clay patches with scattered stones (polygonal or spotted tundra; Chernov, 1985). On slopes and plateaus on tops of hills (up to $50 \mathrm{~m}$ above sea level), the vegetation was generally drier, dominated by grasses, lichens, and dwarf shrubs. In the marshy areas found in valleys, on the lower parts of slopes, and sometimes on hilltops, extensive meadows of sedges Carex spp. predominated. For a more detailed description of the study area, see Schekkerman et al. (2004). Daylight was continuous during the field period.

\section{Weather}

In 2001 and 2002, an automated weather station recorded air temperature, wind speed, wind direction, and precipitation every 30 minutes at our study site. Air temperature was recorded at $1 \mathrm{~m}$ above ground level in the shade, while wind speed and direction were recorded at $10 \mathrm{~m}$ height. Precipitation was measured in $\mathrm{mm} /$ day. In 1996 and 2000, the automated weather station was not yet in use, so only air temperature was measured in the study area and stored in a TinyTag data logger at 30-minute intervals. Data on all other variables (measured at twohourly intervals) were provided by the meteorological station in Dikson, $18 \mathrm{~km}$ north of the study site.

Weather data (daily averages of temperature and wind speed) from Dikson for the years 1973-2005 were obtained through the National Climatic Data Center, National
Oceanic and Atmospheric Administration (www.ncdc. noaa.gov). Given the strong effect of sunshine on the activity of arthropods (Danks, 2004), temperature measured at ground level with a black sphere (a small, hollow metal ball, painted black, with a thermistor inside) may be a better predictor than air temperature. Although we measured black sphere temperatures in 2000-02, we chose to use air temperature in the analyses, because that was the only temperature variable available for the long-term dataset. Because air temperature and black sphere temperature were closely correlated $(r=0.94)$, this choice did not strongly influence our results.

\section{Arthropod Abundance}

The abundance of surface-active arthropods was monitored using pitfall traps. Two lines of five (1996) or ten (other years) white plastic jars $(11 \mathrm{~cm}$ in diameter, $10 \mathrm{~cm}$ deep) were placed along two line transects at intervals of 5-10 m, one in moderately dry polygonal tundra, the other in low-lying, relatively wet, sedge-dominated marsh tundra, the same two tundra types that shorebird broods frequented. The two lines were ca $100 \mathrm{~m}$ apart. The pitfalls were filled with $1-2 \mathrm{~cm}$ formaldehyde solution (4\%) and a drop of detergent to reduce the surface tension. The traps were emptied every evening around 2300 , and samples were sorted and measured immediately or on the next day. Arthropods were sorted into classes or orders-Araneae (spiders), Collembola (springtails), Coleoptera (beetles), Diptera (flies and midges), Hymenoptera (wasps), Crustacea (crustaceans), and Acarina (mites) — and Diptera and Coleoptera were separated into families if possible. Springtails and mites were excluded from the analysis, because we considered them to be too small to be energetically valuable for shorebird and passerine chicks, and their contribution to the total biomass sampled was small. Body length of each arthropod was measured to $0.5 \mathrm{~mm}$ for animals smaller than $5 \mathrm{~mm}$, and to $1 \mathrm{~mm}$ for animals larger than $5 \mathrm{~mm}$. Arthropod dry mass was calculated using the length-dry mass relationships given for different orders in Rogers et al. (1977) and Schekkerman (1997). For orders for which no specific relationship could be found, a general relationship for arthropods was used (Rogers et al., 1976).

The method of pitfall trapping used in this study does not measure absolute abundance of arthropods, but rather a combination of their abundance and surface activity. However, for our purpose of measuring season and weatherinduced variation in arthropod availability for birds, this method served well. Several studies have shown a positive correlation between growth of Arctic shorebird chicks and arthropod catches in 5-10 pitfalls. Schekkerman et al. (2003) found that this correlation remained after effects of temperature, wind, and rainfall on the growth rate of red knot Calidris canutus chicks had been controlled statistically. Conversely, including weather variables did not improve the fit of a model that already contained the number of arthropods caught in five pitfalls. This result 
would only be expected if food availability for chicks were indeed reduced on days with poor pitfall catches. We found similar correlations between pitfall catches and growth rate of chicks of dunlin Calidris alpina and little stint Calidris minuta at our study site during this study. In cold weather, total abundance of arthropods may be the same as on warmer days, but since the arthropods are inactive, it is likely harder for chicks to find them. Although pitfall traps catch only crawling and low-flying insects, this is not a problem given the relative scarcity of high-flying insects in our study area and the fact that shorebird chicks feed only on the ground. Results from a comparative study, in which we used modified white (Malaise) traps equipped with vertical screens to catch insects in flight on top of pitfalls, showed little difference in species composition and catch magnitude from those of the catch made by pitfall traps only (Tulp et al., 1998). It might be argued that a sample size of ten pitfall traps is small. However, variation between traps is minute compared to the day-to-day variation in numbers caught. So the patterns of weather and seasonal effects on arthropod abundance would not be different if the number of traps had been larger.

\section{Statistical Analyses}

Log-linear regression (McCullagh and Nelder, 1989) was used to analyze the effects of season and weather variables on arthropod availability. To allow for overdispersion in the abundance data, a dispersion parameter was estimated in these regressions. Because size of arthropods did not show a normal distribution, log-linear regression models were also used for the analyses of body-size patterns. Variables tested in models to describe the arthropod abundance included date, mean temperature, cumulative mean temperature (accumulated mean daily temperature since the day of snowmelt, treating subzero temperatures as 0 since arthropod activity does not vary once temperatures drop to $0^{\circ} \mathrm{C}$ or below), mean wind speed, quadratic terms of the four preceding parameters (to allow for nonlinear relationships), the occurrence of precipitation (absent/present on the sampling day) and the amount of precipitation ( $\mathrm{mm} /$ day).

The models were built starting with an empty model and testing weather variables after entering date and date ${ }^{2}$ (to allow for a curvilinear pattern). To test the independence of date and weather effects, weather variables were also entered first, after which date and date ${ }^{2}$ were added to the model.

We also considered the possibility that each summer the stock of arthropod larvae, (pre)-pupae or imagines that could potentially emerge on the surface becomes depleted. The number of larvae reaching an adequate developmental stage at the end of the previous summer determines this stock. Because of the clear positive effect of temperature on arthropod surface activity and emergence, the cumulative temperature since the date of snowmelt is correlated with the number of arthropods already emerged since that date (Hodkinson et al., 1996). Therefore, depletion of this stock of potential recruits will become apparent in a negative effect of cumulative temperature on surface arthropod activity after current weather and date have been statistically accounted for. If the possible effect of depletion is tested in single-year analyses, depletion effects become confounded with the seasonal pattern; the effects of date and depletion can therefore be distinguished only in a multi-year analysis.

To test for differences in phenology between the two habitats sampled, we used a loglinear model with dry mass in the two series as the dependent variable and date and date $^{2}$ as predictor variables. If interaction terms date.habitat or date ${ }^{2}$.habitat were significant, the phenology was considered to be different in the two habitats.

\section{RESULTS}

\section{Seasonal and Weather-Related Variation in Surface-Active Arthropod Abundance}

The two habitats generally yielded the same patterns, although in most years biomass was slightly larger in the wet series. In 1996 and 2000, phenologies were similar in the two trap lines, but in 2001 arthropod abundance peaked two days earlier in the wet series (date.habitat $p=0.651$, date.habitat ${ }^{2} p=0.006$ ) while in 2002, arthropod abundance peaked five days later in the wet series, date.habitat $p=$ 0.463 , date.habitat ${ }^{2} p=0.028$ ). The correlation between the daily catches in the two transects was high (1996: $r=0.79$, 2000: $r=0.84,2001: r=0.63,2002: r=0.77)$. Because of the similar patterns found in both series, dry mass values are combined throughout the following analyses.

In three of the four sampling years, the seasonal pattern of total dry mass of arthropods caught in pitfall traps showed a maximum in July (Fig. 1). In 2000, surface arthropod biomass continued to increase until the end of the study period in August. The day-to-day variations were explained largely by weather conditions. As date and weather are partly correlated, it is difficult to distinguish between these effects. After adding date + date $^{2}$, weather variables (precipitation in 1996; temperature, wind speed and precipitation in 2000; temperature, temperature ${ }^{2}$ and precipitation in 2001; and temperature and temperature ${ }^{2}$ in 2002) significantly improved the models that described patterns in total dry mass (Table 1). Total explained deviances varied between years from $42 \%$ to $89 \%$. The lower explanatory power of the model for 1996 is caused by the shorter time series and smaller variation in weather data. In three out of four years, entering date+date ${ }^{2}$ after the weather variables instead of before resulted in the same set of significant variables. Only in 2002 were date and date ${ }^{2}$ no longer significant. Hence most years had both a unimodal seasonal pattern with a midsummer maximum and additional variation caused by weather. The amplitude of this 


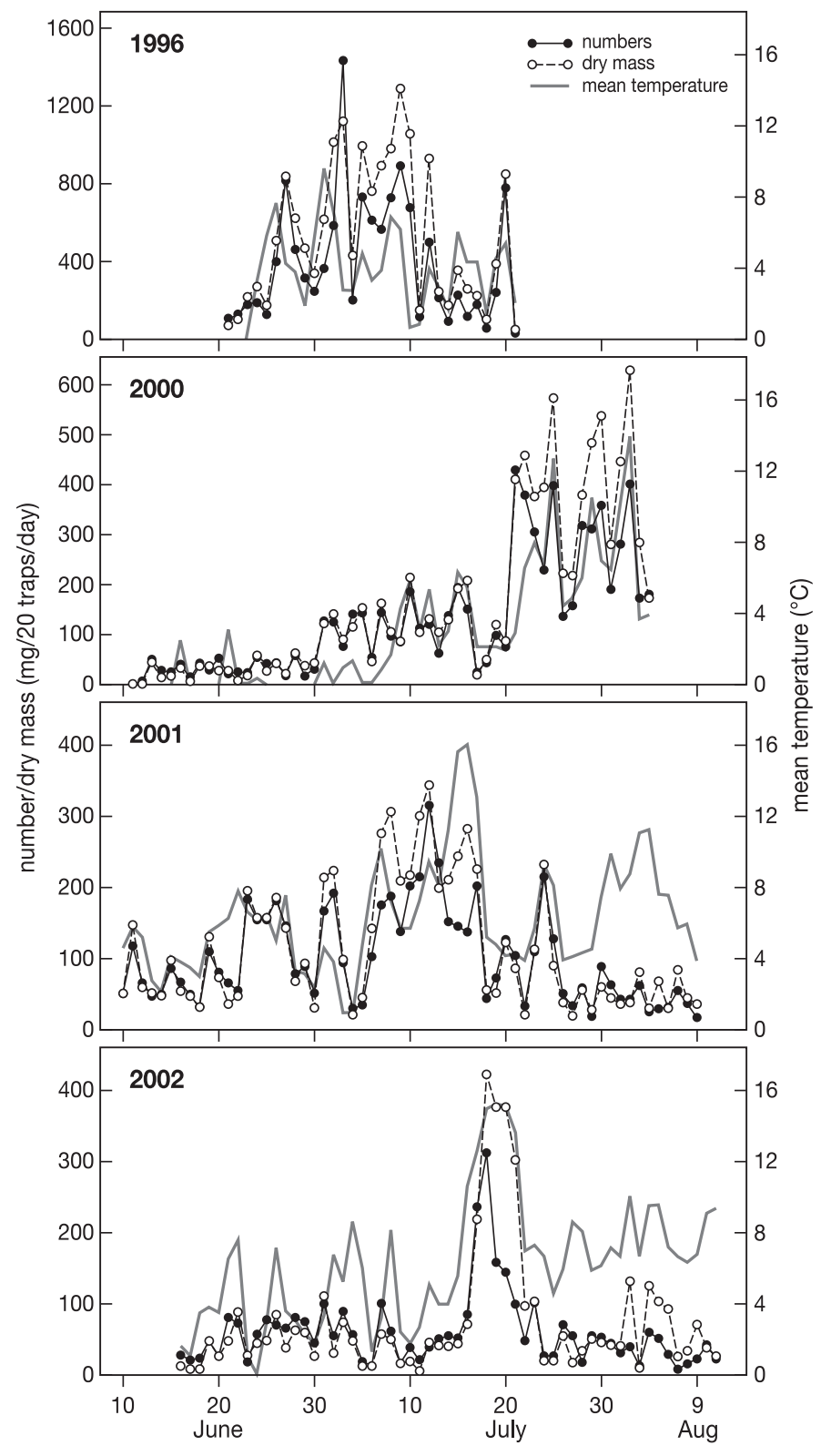

FIG. 1. Seasonal changes in numbers and dry mass of arthropods and mean air temperature in 1996 and 2000-02.

short-term variation was as large as that of the seasonal effect (Fig. 1).

\section{Seasonal Variation in Size of Arthropods}

In all years, average body length of arthropods increased with season (Fig. 2, date and date ${ }^{2} p<0.01$ for all years). Because the body length of insects that have reached their adult phase usually remains stable, the seasonal cline in size must be caused by a trend in the size of emerging arthropods, i.e., small individuals or species emerging earlier than larger ones. Because the various insect families showed relatively small within-group variation in size, the main cause of variation was the phenology of different families. The change in average size is explained predominantly by the emergence of the largest-sized family, crane flies or Tipulidae (Diptera, Fig. 3). Because of their slow locomotion, large size, and partial winglessness, tipulids are likely to be an important prey for chicks (Holmes and Pitelka, 1968; Pearce-Higgins and Yalden, 2004). They emerged in a relatively short and peaked period (Fig. 3). The maximum contribution of crane flies to total biomass on a day was $86 \%$.

\section{Modeling the Peak in Arthropod Abundance}

The measurements of arthropod abundance in relation to weather and date were used to model seasonal patterns in arthropod abundance for a period of 33 years (19732005). Over this period, mean temperature in June-August increased significantly in the study area $\left(0.05^{\circ} \mathrm{C}\right.$ annually). This increase was the result of a temperature rise in July and August, but not in June (Fig. 4).

Data from all four years were used to fit one model describing arthropod biomass with the same variables used in the analysis for separate years, including year as an extra factor, but excluding precipitation, because data were not available for the 33-year period. Year, date, (plus quadratic term), temperature, cumulative temperature (plus quadratic term), and wind all significantly contributed to the model (Table 2) and together explained $74 \%$ of the total deviance. Restricting this analysis to tipulids yielded a similar model (but without wind and the cumulative effect of temperature) and explained $54 \%$ of the deviance.

For the years in which arthropod abundance was measured, the fitted model closely matched the actual values, both for total arthropods and for tipulids only (correlations for all arthropods between 0.70 and 0.90 , for tipulids 0.71 and 0.88, Fig. 5). Using this model, we then estimated abundance of arthropods (and tipulids separately) for the years 1973-2005 on the basis of the measured weather data. Because year effects cannot be extrapolated outside the sampling period, we used the average of the year effects for the four sampling years in our predictions. The year effect determines variation in overall population level between years, but not the seasonal patterns within years, which is our main interest.

Dates of peak occurrence in every year were determined by fitting a second-order polynomial (date + date $\left.^{2}\right)$ to the predicted arthropod abundance (log-transformed) and calculating the date on which the first derivative of each year model equaled zero. In 1973-2005, peak dates ranged between 8 and 31 July and occurred most often on 17 July and 20 July (each date in four years) (median peak date = 19 July, Fig. 6). Over the 33-year period, the peak date advanced, on average, by $0.2(\mathrm{SE}=0.07)$ days per year, resulting in a total advancement of 7 days $\left(\mathrm{F}_{1,31}=5.75\right.$, $p=0.02, \mathrm{R}^{2}=0.16$, Fig. 7). The average deviation of the modeled peak date from the long-term average, corrected for the long-term trend, was \pm 4 days (range $0-10$ days).

For chicks it may be more important to encounter a food supply sufficient for growth than to hit the actual peak in 
TABLE 1. Analysis of seasonal trend in total dry mass of arthropods (per 20 traps per day) including weather variables at Medusa Bay in 1996, 2000, 2001, and 2002. The null model includes only the constant, the final model includes all significant parameters shown. The parameters tested were date (day number since 1 June), mean temperature (in ${ }^{\circ} \mathrm{C}$ ), cumulative mean temperature since 1 June, mean wind speed (wind in $\mathrm{m} \cdot \mathrm{s}^{-1}$ ) plus quadratic terms and precipitation (in $\mathrm{mm}$ per day). In all cases precipitation gave a better fit as a continuous variable than as a categorical variable. If date ${ }^{2}$ was significant but date was not, both were included in the model.

\begin{tabular}{|c|c|c|c|c|c|c|}
\hline Year & Model & $\mathrm{df}$ & Change in Deviance & $p$ & Coefficient & SE \\
\hline \multirow[t]{6}{*}{1996} & constant & & & & -1.0600 & 2.1400 \\
\hline & null model & 30 & 8936.0 & & & \\
\hline & final model & 3 & 3751.0 & & & \\
\hline & date & 1 & 0.7 & 0.953 & 0.4430 & 0.1210 \\
\hline & date $^{2}$ & 1 & 2931.0 & $<0.001$ & -0.0063 & 0.0017 \\
\hline & precipitation & 1 & 820.0 & 0.050 & 0.0566 & 0.0259 \\
\hline \multirow[t]{8}{*}{2000} & constant & & & & 2.0030 & 0.5960 \\
\hline & null model & 53 & 8056.9 & & & \\
\hline & final model & 5 & 7210.2 & & & \\
\hline & date & 1 & 5713.8 & $<0.001$ & 0.1239 & 0.0253 \\
\hline & date $^{2}$ & 1 & 203.6 & 0.001 & -0.0011 & 0.0003 \\
\hline & temperature & 1 & 770.3 & $<0.001$ & 0.1118 & 0.0160 \\
\hline & wind & 1 & 415.1 & $<0.001$ & -0.0974 & 0.0276 \\
\hline & precipitation & 1 & 107.5 & 0.015 & -0.9500 & 0.4100 \\
\hline \multirow[t]{8}{*}{2001} & constant & & & & 1.9280 & 0.4560 \\
\hline & null model & 60 & 3831.0 & & & \\
\hline & final model & 5 & 2593.0 & & & \\
\hline & date & 1 & 51.8 & $<0.001$ & 0.1144 & 0.0213 \\
\hline & date $^{2}$ & 1 & 1436.8 & $<0.001$ & -0.0016 & 0.0003 \\
\hline & temperature & 1 & 687.0 & $<0.001$ & 0.2716 & 0.0697 \\
\hline & temperature ${ }^{2}$ & 1 & 181.0 & 0.006 & -0.0102 & 0.0037 \\
\hline & precipitation & 1 & 236.2 & 0.002 & -0.1386 & 0.0466 \\
\hline \multirow[t]{7}{*}{2002} & constant & & & & 3.0820 & 0.7060 \\
\hline & null model & 54 & 4159.0 & & & \\
\hline & final model & 4 & 3285.3 & & & \\
\hline & date & 1 & 271.4 & $<0.001$ & 0.0201 & 0.0342 \\
\hline & date $^{2}$ & 1 & 645.2 & $<0.001$ & -0.0002 & 0.0004 \\
\hline & temperature & 1 & 2263.9 & $<0.001$ & 0.0095 & 0.0788 \\
\hline & temperature ${ }^{2}$ & 1 & 104.9 & 0.016 & 0.0099 & 0.0040 \\
\hline
\end{tabular}

abundance. Red knot chicks were able to grow normally only when arthropod biomass caught in pitfalls exceeded approximately $200 \mathrm{mg}$ per 20 traps per day, and the chicks' growth was severely retarded when arthropod biomass dropped to levels below $100 \mathrm{mg}$ per 20 traps per day (Schekkerman et al., 2003). Choosing $200 \mathrm{mg}$ as a general approximation of a food situation that allows sufficient growth for chicks, we calculated the probability that this level was reached in the model predictions for each date in the period 1973-2005. This probability seldom exceeded $40 \%$ (Fig. 6, lower panel), indicating that even at the height of the insect season, days with adverse feeding conditions are common. The probability that arthropod biomass caught was greater than $100 \mathrm{mg}$ exceeded $50 \%$ continuously in the period 10 July to 9 August.

To evaluate possible long-term changes in the timing of the total period when birds have a reasonable probability of finding enough food to grow, we analyzed probabilities that biomass exceeds 100 or $200 \mathrm{mg} /$ day/20 traps, separately for three consecutive 11-year periods: 1973-83, 1984-94, and 1995-2005. The general pattern derived from this comparison is that days with enough food supply for chicks to grow have moved to earlier in the year. For the $200 \mathrm{mg}$ limit, the first period (1973-83) differed significantly from the last period (1995-2005, Kolgomorov-Smirnov test $\chi^{2}=6.28, p=0.043$ ), but not from the second period, nor was there a difference between the second and third periods. For the $100 \mathrm{mg}$ limit, the first period differed from the last period $\left(\chi^{2}=8.70, p=0.013\right)$ and the last two periods differed as well $\left(\chi^{2}=6.28\right.$, $p=0.043)$. The number of days in June, July, and August with a probability of a minimum of $100 \mathrm{mg}$ has increased significantly in the 33 years $\left(\mathrm{F}_{1,31}=16.63, p<0.001\right.$, $\mathrm{R}^{2}=0.35$ ). The length of the season (number of days between the first and the last date with probabilities that arthropod mass caught exceeds $100 \mathrm{mg}$ ) has remained unchanged (limit: $\mathrm{F}_{1,31}=0.42, p=0.52$ ). Similar results were found when using the $200 \mathrm{mg}$ limit: (increase in number of days: $\mathrm{F}_{1,31}=6.44, p=0.016, \mathrm{R}^{2}=0.17$; length of season: $\mathrm{F}_{1,31}=0.26, p=0.61$ )

\section{DISCUSSION}

\section{Patterns in Arthropod Abundance}

In this paper we used total catches of arthropods in pitfalls, summed over many taxa, as a measure of food availability to 


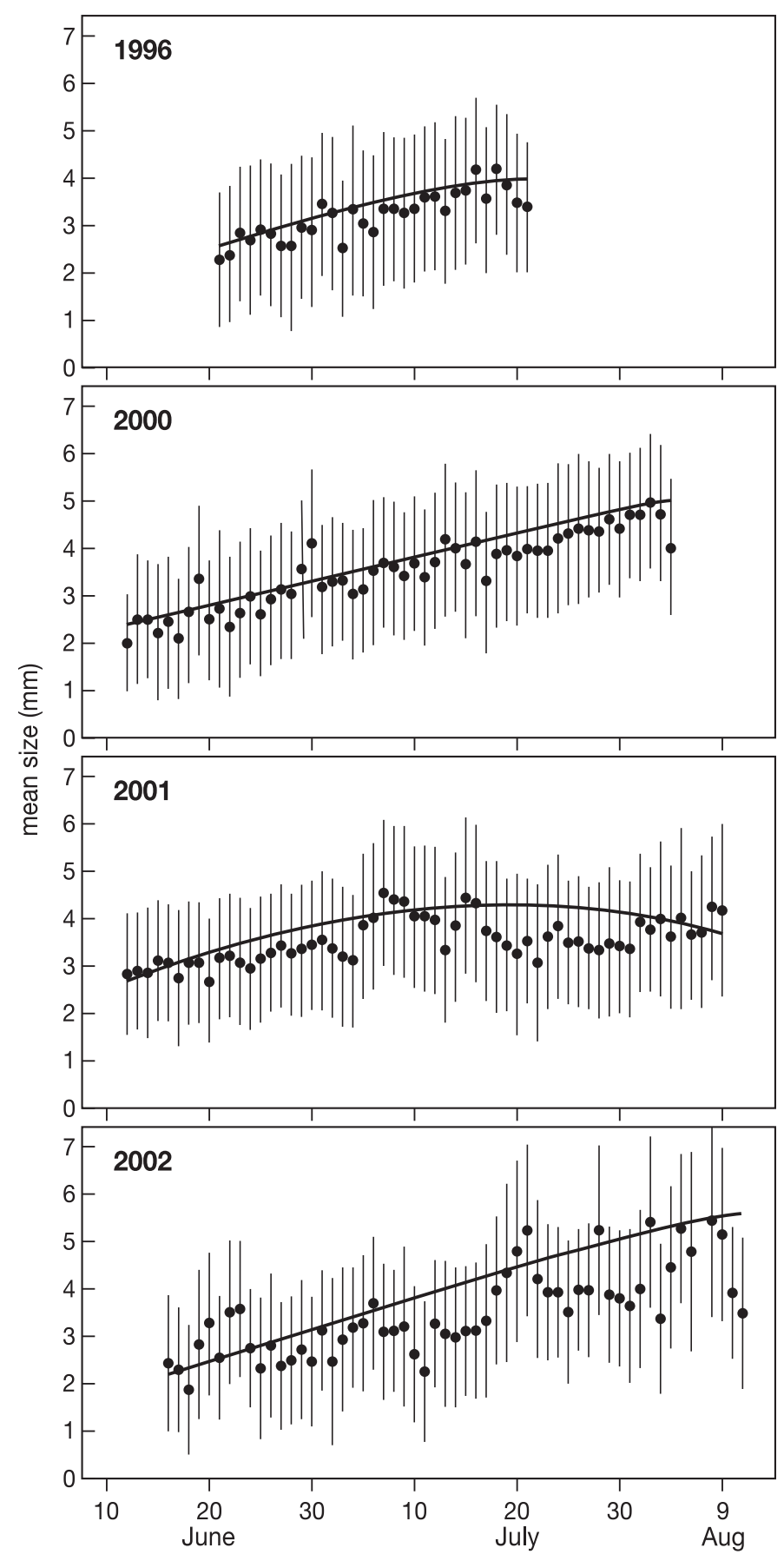

FIG. 2. Mean size and standard deviation of arthropods per day in 1996 and 2000-02. The curves represent the fitted loglinear regression lines.

tundra insectivores. Arctic shorebird diets comprise a wide range of arthropod taxa (Holmes and Pitelka, 1968); therefore, these totals are likely to provide a useful index of food availability, although bird species may show some differences in the relative share of various arthropod taxa.

We have shown that the variation in the activity and abundance of surface-active tundra arthropods is explained to a large extent by date and weather. Superimposed on a unimodal seasonal pattern were strong influences of temperature, wind, and precipitation. Similar close correlations with weather have been observed in other studies in both

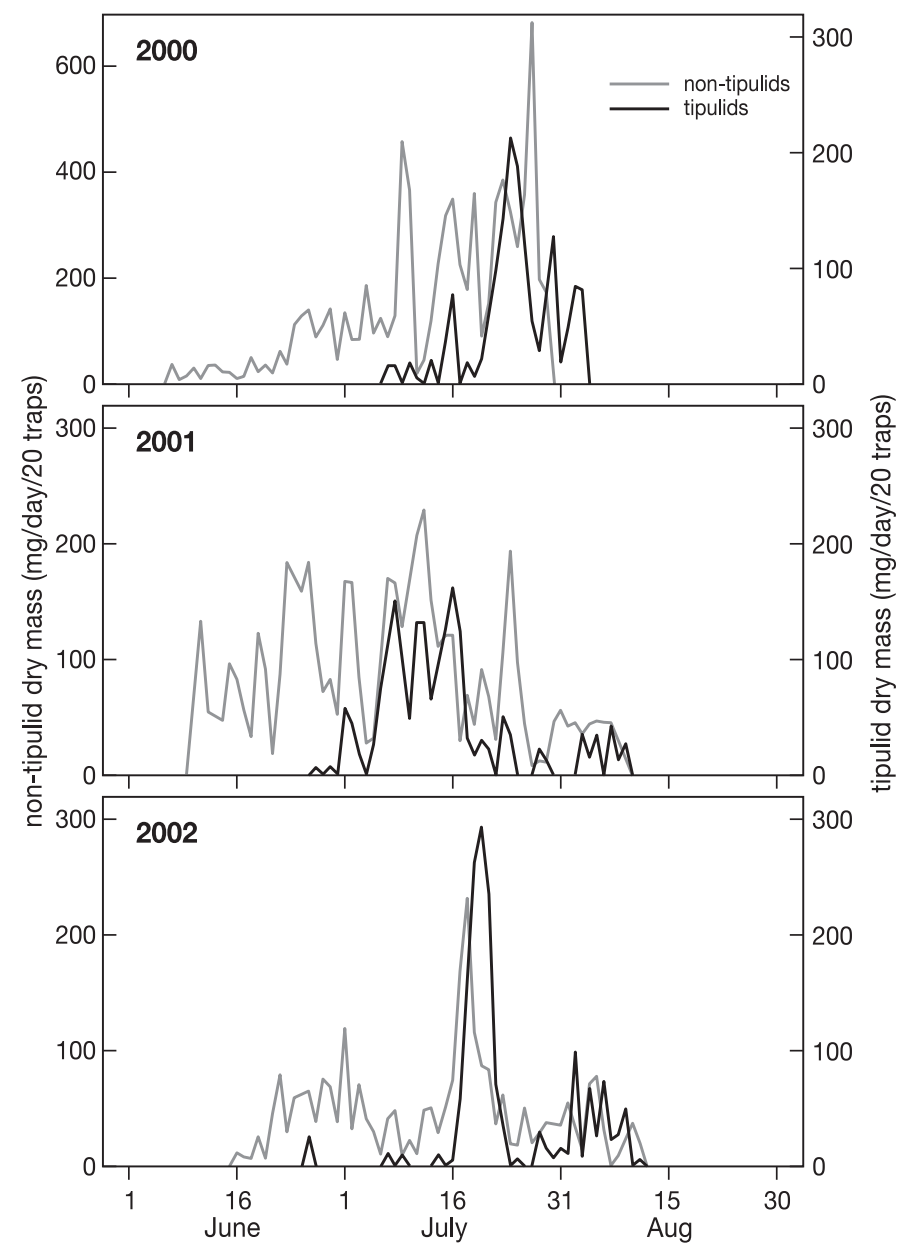

FIG. 3. Dry mass caught in the pitfall traps for tipulids and all other groups (nontipulid) separately.

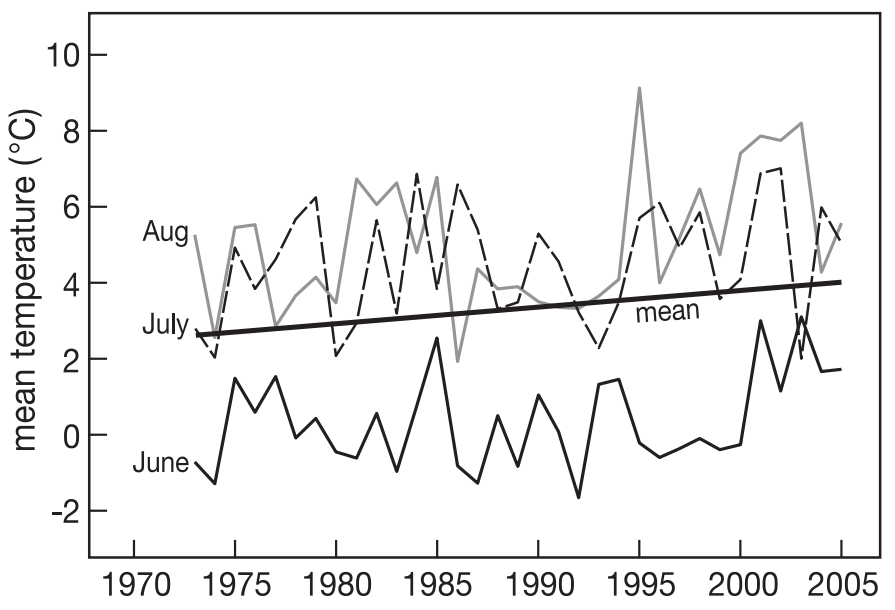

FIG. 4. Mean temperature in June, July, and August in the period 1973-2005. The line is the linear regression of mean temperature in the three months $\left(\mathrm{F}_{1,31}=7.8, p=0.008\right)$.

temperate and Arctic areas (MacLean and Pitelka, 1971; Goulson et al., 2005). The reduction in arthropod mass caught in pitfall traps during cold weather can be explained by mortality, reduced emergence in response to adverse weather, and a reduction in activity, or some combination of 
TABLE 2. Results of loglinear regression of weather and seasonal related variables on arthropod dry mass, used to model arthropod abundance in 1973-2005. The null model includes only the constant; the final model includes all significant parameters shown. The parameters tested included date, temperature (in ${ }^{\circ} \mathrm{C}$ ), cumulative temperature since 1 June, and wind speed (wind in $\mathrm{m}^{\bullet} \mathrm{s}^{-1}$ ), plus all quadratic terms.

\begin{tabular}{|c|c|c|c|c|c|c|}
\hline Response Variable & Model & Change in Deviance & df & $p$ & Coefficient & SE \\
\hline $\begin{array}{l}\text { total dry mass/ } \\
20 \text { traps/day }\end{array}$ & $\begin{array}{l}\text { null model } \\
\text { final model } \\
\text { year } \\
1996 \\
2000 \\
2001 \\
2002 \\
\text { constant } \\
\text { date } \\
\text { date }^{2} \\
\text { temperature } \\
\text { cumulative temperature }_{\text {cumulative temperature }}^{2} \\
\text { wind speed }\end{array}$ & $\begin{array}{r}2051 \\
2044 \\
7486 \\
253 \\
535 \\
249\end{array}$ & $\begin{array}{r}200 \\
6 \\
3\end{array}$ & $\begin{aligned}<0.001 \\
\\
\\
<0.001 \\
<0.001 \\
<0.001 \\
0.043 \\
0.003 \\
0.044\end{aligned}$ & $\begin{array}{l}0 \\
-1.317 \\
-1.770 \\
-2.197 \\
4.942 \\
0.0320 \\
-0.000399 \\
0.1306 \\
0.00816 \\
-0.00002710 \\
-0.0383\end{array}$ & $\begin{array}{l}0 \\
0.129 \\
0.303 \\
0.195 \\
0.576 \\
0.0298 \\
0.000332 \\
0.0133 \\
0.00536 \\
0.00000944 \\
0.0191\end{array}$ \\
\hline
\end{tabular}
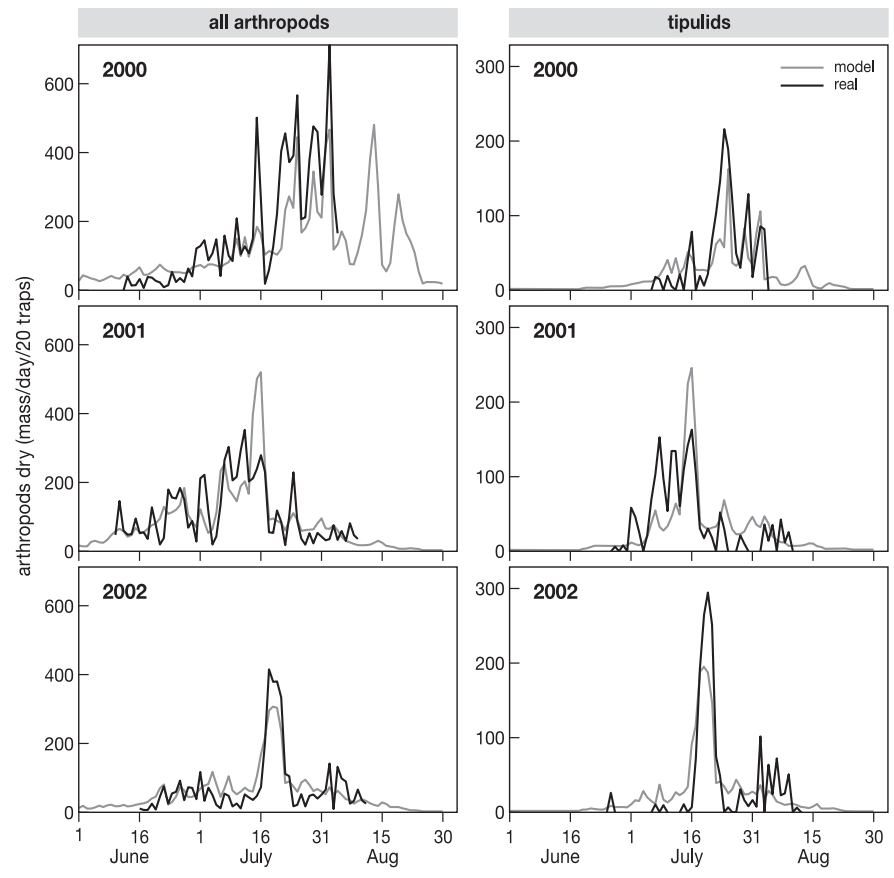

FIG. 5. Comparisons between model predictions and actual dry mass caught in the pitfall traps in 2000, 2001, and 2002. (Data for 1996 are not presented here because the field season was not complete.) Correlations between model outcomes and measured values for total arthropods are 0.90 for $2000,0.70$ for 2001, and 0.90 for 2002. Comparable figures for tipulids are $0.76,0.72$, and 0.89 .

these factors. In cold conditions, arthropods seek thermally favourable sites and retreat into the moss layer or soil, thus becoming less available to birds (Danks, 2004).

The significant contribution of cumulative temperature (plus its quadratic term) to the fit of the models already containing date and weather variables indicates that the total number of arthropods ready to emerge can become depleted over the season. This contributes to the peaked seasonal pattern of arthropod availability for birds and causes food availability to decline well before declining temperatures reach a threshold that would reduce developmental rates and survival of surface-active arthropods.
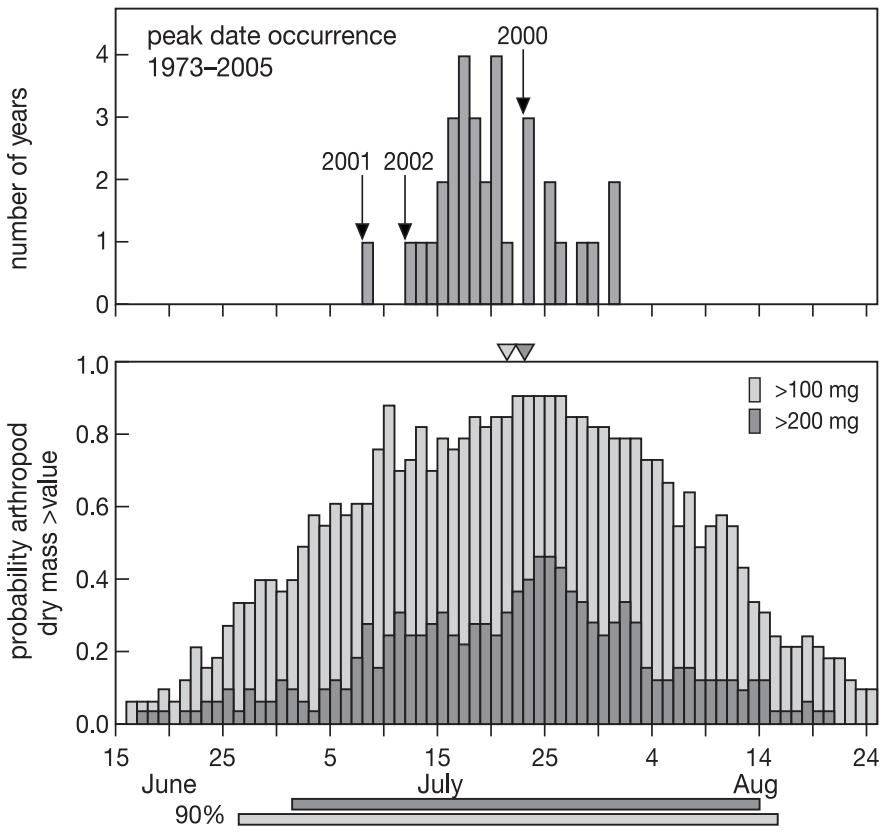

FIG. 6. Frequency distribution of the occurrence of peak dates in arthropod abundance (upper graph, bars) in the period 1973-2005. Arrows indicate the peak dates for the years 2000, 2001, and 2002. (1996 is omitted because the field data do not cover the whole period.) The lower graph represents the probability that total dry mass caught in pitfall traps exceeds the limit of 100 or $200 \mathrm{mg} / \mathrm{day} /$ 20 traps in the period 1973-2005. The triangles indicate median dates, and the bars show the central $90 \%$ of the distribution.

Weather, date, and depletion effects together explained a major part of the total variation in arthropod abundance over our sampling years (Table 2). This good fit allowed us to hindcast within-year patterns in surface arthropod activity over a long period in the past with some confidence. In the absence of long-term data sets on actual measured arthropod abundances, this exercise provides insights into the variability in timing of food availability for Arctic insectivores.

The peaks in arthropod abundance fell on 23 July in 2000,8 July in 2001, and 12 July in 2002. Compared to the 


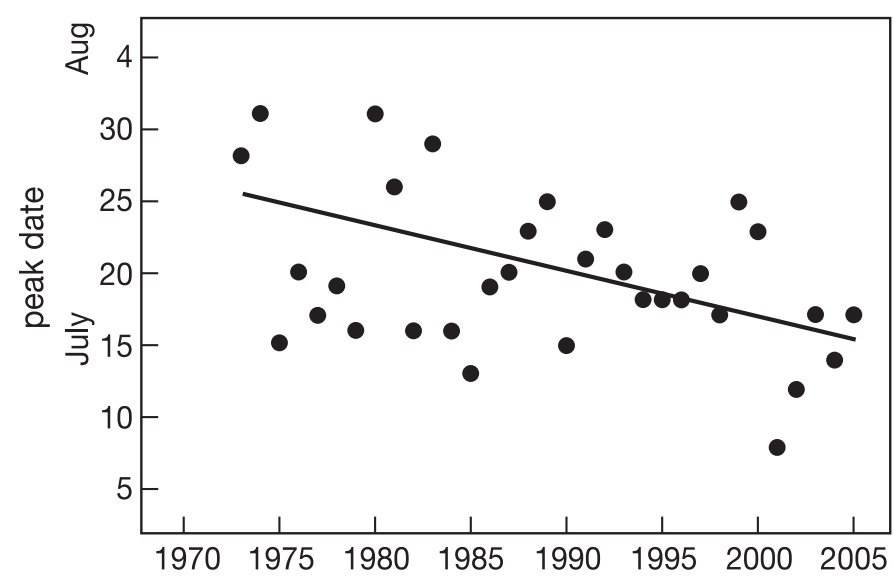

FIG. 7. Predicted timing of the annual peak in arthropod abundance in $1973-$ 2005.

33-year period of weather data, 2001 and 2002 were among the years with the earliest peaks in temperature and hence arthropod abundance, but 2000 showed one of the latest peaks (Fig. 6). The occurrence of these extremes within the observation period means that over $75 \%$ of all years fell within the range captured during our study.

As a consequence of the large variation characteristic of Arctic weather (Myers and Pitelka, 1979) and its strong effects on arthropod activity, the predictability of the timing of food availability for Arctic-breeding birds in any single year is rather poor (Fig. 8). In our 33-year set, the average deviation of the modeled peak date from the long-term average corrected for the long-term trend was four days.

For chick growth, the exact timing of the peak itself is less important than the occurrence of enough days with sufficient food availability during their growth period. Several consecutive days with adverse weather and low food levels can severely reduce chick survival (Schekkerman et al., 1998, 2003). Our modeling indicated that over the past decades not only has the date of peak occurrence become earlier, but also the range of dates with a good probability for the birds to find sufficient food for normal growth. A potential problem with this second measure of the timing of food availability for birds is that it involves an absolute estimate of arthropod availability (< or $>100$ or $200 \mathrm{mg}$ ) and not only a within-year comparison of abundance like in the modeling of peak dates. Because our model cannot predict variation between years in overall levels of arthropod abundance, using instead the average of the four observation years, it cannot predict the probability of finding enough food with the same confidence as the peak date of abundance. However, variation in overall insect abundance between years is more likely to affect the mean level of the calculated probabilities than their distribution over dates. Therefore, we interpret the advancement of the probability distributions towards earlier dates as a strong indication that the period with sufficient food availability for reproduction has indeed advanced. The questions remain whether southern arthropod species will migrate north, and when, and whether this

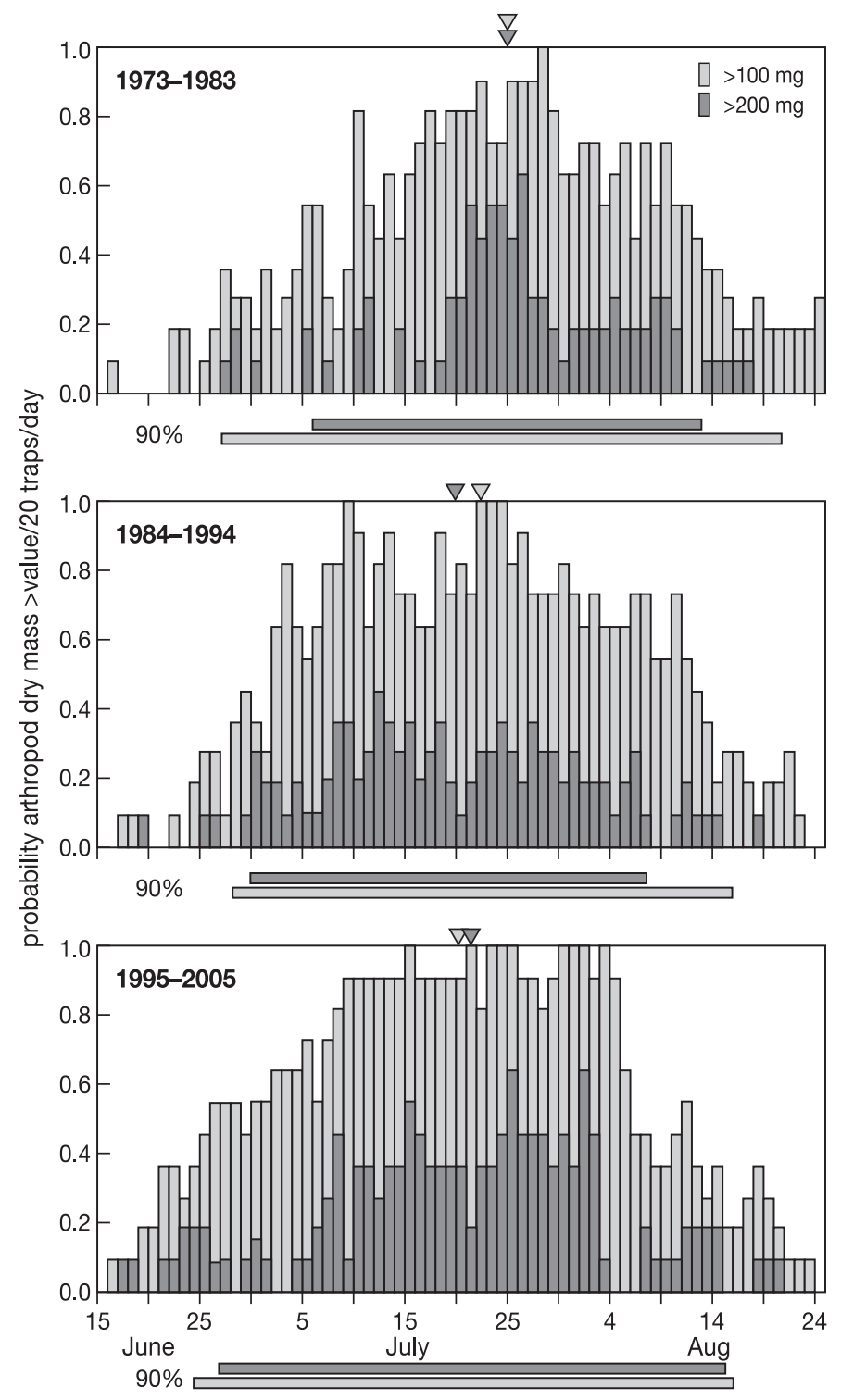

FIG. 8. The probability that total dry mass caught in pitfall traps exceeds the limit of 100 and $200 \mathrm{mg} /$ day/20 traps in three periods: $1973-83,1984-94$, and 1995-2005. The triangles indicate median dates; the bars, the central $90 \%$ of the distribution.

migration will affect the total amount of arthropod productivity. Of course, there is no substitute for actual measurements, so we urge researchers to set up long-term monitoring of arthropod abundance patterns in the Arctic and to study the underlying mechanisms generating those patterns. Also, the pattern detected in our study area might not be a general one for the Arctic. To evaluate how our site in Taimyr compares to others in this respect, our approach should be applied to other sites as well.

\section{Repercussions of an Earlier Peak in Arthropod Abundance for Birds}

Breeding success in birds depends to a large extent on food availability for the chicks (Lack, 1968; Lindholm et al., 1994; Pearce-Higgins and Yalden, 2004). In shorebirds, 
breeding is ideally timed so that chicks hatch during or just before the peak in food availability (Hurd and Pitelka, 1954; Holmes, 1966a, b; Schekkerman et al., 1998, 2003). Given the strong seasonality in chick growth and survival (Schekkerman et al., 1998; Tulp and Schekkerman, 2001) and the relationship between surface arthropod abundance and chick growth (Schekkerman et al., 2003), the synchronicity of Arctic shorebird breeding with the seasonal peak in food supply may be crucial to successful reproduction. In our study period, the timing of peak arthropod abundance varied greatly between years, and even during the peak period, food abundance was highly unpredictable because of strong day-to-day variations in weather. Shorebirds in our study area and elsewhere in the Arctic seem to deal with this uncertainty by starting to breed as early as possible after the snow melts (Schekkerman et al., 2004; Meltofte et al., 2007). In this way, they maximize the probability that chicks hatch when food peaks. The risk that this strategy would result in the eggs hatching too early is very small because arthropod abundance starts to build up immediately after snowmelt. In years with an early snowmelt, such as 2000 , the period between the start of the first nest and the last nest is much longer than in years with late snowmelt, such as 2002 (Schekkerman et al., 2004). This difference results from the fact that the last nests were initiated no later than 15 July in all years, indicating that the opportunities for successful reproduction decline or are abruptly truncated later in the season. Studies on breeding phenology in Arctic passerines also show that territories are established during snowmelt, and that chicks fledge when food is most abundant (Seastedt and MacLean, 1979).

Across the period 1973-2005, both the peaks in arthropod abundance and the dates with reasonable probabilities of encountering enough food for chicks become earlier, while the length of the period with sufficient food availability has not changed (Fig. 7). How can birds respond to these changes?

Birds use different cues to determine the onset of breeding. Direct measures of food abundance may not be reliable because gonad development and egg laying take place well before the arthropod peak. If cues that trigger the start of breeding are related to climate change in the same way as the insect peak, birds would be able to track these changes. If, however, the cues used are not correlated with the timing of the insect peak, an advancement of the period of food availability may result in poor timing of reproduction. The breeding phenology of Arctic shorebirds has been shown to be correlated with interannual variation in the timing of snowmelt, with a smaller additional effect of temperature during the pre-laying period (Green et al., 1977; Meltofte, 1985; Holmgren et al., 2001). An early start of breeding for these ground-nesting birds is only possible if there is enough snow-free area. If the timing of snowmelt has advanced less than the seven days of the arthropod peak advance over the past 33 years, the length of the season suitable for breeding would have shortened over this period. Although long-term data on the date of snowmelt in the study area are not available, there are several indications that the onset of snowmelt has advanced generally in northern Eurasia and other Arctic areas (Dye, 2002; Stone et al., 2002; Dye and Tucker, 2003; Walsh, 2005). However, given the high geographical variability in the Arctic, long-term local data on snow cover are needed to evaluate whether these two developments keep pace with each other.

\section{Possibilities to Advance Timing of Breeding by Adjusting Migration Schedules}

Most Arctic-breeding birds are seasonal migrants that winter at great distances from their breeding areas. Because the period between arrival on the breeding grounds and breeding is generally short (Schekkerman et al., 2004; Meltofte et al., 2007), an earlier onset of breeding is possible only if birds arrive earlier. That can be achieved by an earlier departure from the wintering grounds, an increase in migration speed, or a shortening of migration distance (Coppack and Both, 2002). A long-distance migrant songbird, the pied flycatcher Ficedula hypoleuca, tended to arrive from tropical Africa and breed earlier, although not early enough to track the advancing peak in food supply (Both and Visser, 2001; Coppack and Both, 2002; Both et al., 2005). This mismatch has already resulted in a significant decrease of the population (Both et al., 2006). Some factor apparently prevents an earlier arrival on the breeding grounds.

The start of spring migration in long-distance migrant birds is induced by an internal clock, synchronized with changes in day length (Gwinner, 1996). Although accelerating migration in response to increasing temperatures even in non-breeding areas and along the route has been shown in pied flycatchers (Ahola et al., 2004) and in a study of 20 migrant landbirds (Cotton, 2003), changes in the breeding areas may not be perceivable or predictable by birds before their arrival (Visser et al., 2004). This may apply especially to the many species of shorebirds that cover the distance from their intertidal non-breeding and stopover areas to the northern breeding sites in just a few long, non-stop flights (Henningsson and Alerstam, 2005). The species that make their final jump from latitudes close to their breeding sites, as some shorebird species along the Pacific Flyway do (B. McCaffery pers. comm. 2006), will be less affected. In the long term, adjustment could take place through selection for earlier arriving birds, although this is likely to occur at a slower rate than the advancement of seasonality (Both and Visser, 2001; Coppack and Both, 2002; Both et al., 2005). Evidence for the latter mechanism has already been found in long-distance migratory songbirds that are leaving Africa earlier (Jonzen et al., 2006). Such selection is conceivable unless speeding up migration is constrained by dependence on prey that is only available for a limited period of time in specific stopover areas, a phenomenon known for a few shorebird-prey combinations (Zwarts, 1990; Zwarts and 
Blomert, 1990; Baker et al., 2004). In theory, at critical stopovers, the availability of time-constrained resource flushes (food resources available only temporarily), if they are temperature-dependent, could also occur earlier in response to climate change. Their advancement might mitigate some of the costs of changing migration schedules. To date, very few studies have been published on long-term trends in timing of arrival and breeding of Arctic shorebirds and passerines. Determining whether Arctic shorebird populations will be able to adapt to a changing phenology of their food resources and what the effect of such changes will be on reproductive output will require long-term observation programs.

\section{ACKNOWLEDGEMENTS}

The expeditions in 2000-02 and the subsequent data analyses were made possible through participation in the flyway project in the North-South program, which was financed by the Dutch Ministry of Agriculture and Nature Management and Food Safety (division DWK ). The following organizations and people contributed to the expeditions: the staff of the Great Arctic Reserve, Gerard Boere, Bart Ebbinge, Pavel Tomkovich, Gerard Müskens, Sergei Kharitonov, Sergei, Katya and Aleksej Dudko, Alexander Beliashov, Sergei Kharitonov, Andrei Bublichenko, Mikhail Berezin, Tatyana Peredalova, Tatyana Varlygina, and Tatyana Kirikova. Leo Bruinzeel, Joop Jukema, Kathy Calf, Raymond Klaassen, Oscar Langevoord, Joep de Leeuw, Leon Peters, and Olga Stepanova helped collect the data. I. Tulp received research grants from the Nederlandse Organisatie voor Wetenschappelijk Onderzoek (Netherlands Organization for Scientific Research) in 2000 and from the European Science Foundation in 2001. This paper benefited greatly from comments made by Theunis Piersma, Bruno Ens, Peter Kevan, Brian McCaffery, Richard Ring, and two anonymous reviewers of previous versions of the manuscript.

\section{REFERENCES}

AHOLA, M., LAAKSONEN, T., SIPPOLA, K., EEVA, T., RAINIO, K., and LEHIKOINEN, E. 2004. Variation in climate warming along the migration route uncouples arrival and breeding dates. Global Change Biology 10:1610-1617.

ANDREEV, A.V. 1999. Energetics and survival of birds in extreme environments. Ostrich 70:13-22.

BAKER, A.J., GONZÁLEZ, P.M., PIERSMA, T., NILES, L.J., DO NASCIMENTO, I.D.L.S., ATKINSON, P.W., CLARK, N.A., MINTON, C.D.T., PECK, M.K., and AARTS, G. 2004. Rapid population decline in red knots: Fitness consequences of decreased refuelling rates and late arrival in Delaware Bay. Proceedings of the Royal Society of London, Series B-Biological Sciences 271:875-882.

BOTH, C., and VISSER, M.E. 2001. Adjustment to climate change is constrained by arrival date in a long-distance migrant bird. Nature 411:296-298.
BOTH, C., BIJLSMA, R.G., and VISSER, M.E. 2005. Climatic effects on timing of spring migration and breeding in a longdistance migrant, the pied flycatcher Ficedula hypoleuca. Journal of Avian Biology 36:368-373.

BOTH, C., BOUWHUIS, S., LESSELLS, C.M., and VISSER, M.E. 2006. Climate change and population declines in a longdistance migratory bird. Nature 441:81-83.

CALLAGHAN, T.V., BJORN, L.O., CHERNOV, Y.I., CHAPIN, T., CHRISTENSEN, T.R., HUNTLEY, B., IMS, R.A., JOLLY, D., MATVEYEVA, N., PANIKOV, N., OECHEL, W., and SHAVER, G. 2005. Arctic tundra and polar desert ecosystems. In: Arctic climate impact assessment. Cambridge: Cambridge University Press. 243-352.

CAREY, C. 1986. Avian reproduction in cold climates. Proceedings of the International Ornithological Congress 19:2708-2715.

CHERNOV, Y.I. 1978. Adaptive features of life-cycles of tundra zone insects. Zhurnal Obshchei Biologii 39:394-402.

. 1985. The living tundra. Cambridge: Cambridge University Press.

COPPACK, T., and BOTH, C. 2002. Predicting life-cycle adaptation of migratory birds to global climate change. Ardea 90:369-378.

COTTON, P.A. 2003. Avian migration phenology and global climate change. Proceedings of the National Academy of Sciences of the United States of America 100(21):12219-12222.

CUSTER, T.W., and PITELKA, F.A. 1978. Seasonal trends in summer diet of Lapland longspur near Barrow, Alaska. The Condor 80:295-301.

DANKS, H.V. 1981a. Arctic arthropods: A review of systematics and ecology with particular reference to North American fauna. Ottawa: Entomological Society of Canada.

1981b. Bibliography of Arctic arthropods of the Nearctic region. Ottawa: Entomological Society of Canada.

- 1999. Life cycles in polar arthropods-flexible or programmed? European Journal of Entomology 96:83-102.

- 2004. Seasonal adaptations in Arctic insects. Integrative and Comparative Biology 44:85-94.

DOWNES, J.A. 1981. Temporal and spatial changes in the North American insect fauna. Canadian Entomologist 112:1089-1238.

DYE, D.G. 2002. Variability and trends in the annual snow-cover cycle in Northern Hemisphere land areas, 1972-2000. Hydrological Processes 16:3065-3077.

DYE, D.G., and TUCKER, C.J. 2003. Seasonality and trends of snow-cover, vegetation index, and temperature in northern Eurasia. Geophysical Research Letters 30(7), 1405, doi:10.1029/ 2002 GL016384.

GOULSON, D., DERWENT, L.C., HANLEY, M.E., DUNN, D.W., and ABOLINS, S.R. 2005. Predicting calyptrate fly populations from the weather, and probable consequences of climate change. Journal of Applied Ecology 42:796-804.

GREEN, G.H., GREENWOOD, J.J.D., and LLOYD, C.S. 1977. Influence of snow conditions on date of breeding of wading birds in Northeast Greenland. Journal of Zoology 183:311-328.

GWINNER, E. 1996. Circannual clocks in avian reproduction and migration. Ibis 138:47-63.

HART, J.D., MILSOM, T.P., FISHER, G., WILKINS, V., MOREBY, J., MURRAY, A.W.A., and ROBERTSON, P.A. 2006. The relationship between yellowhammer breeding 
performance, arthropod abundance and insecticide applications on arable farmland. Journal of Applied Ecology 43:81 -91.

HELMERS, D.L., and GRATTO-TREVOR, C.L. 1996. Effects of predation on migratory shorebird recruitment. In: Transactions of the 61st North American Wildlife and Natural Resources Conference. Washington, D.C.: Wildlife Management Institute. $50-61$.

HENNINGSSON, S.S., and ALERSTAM, T. 2005. Barriers and distances as determinants for the evolution of bird migration links: The Arctic shorebird system. Proceedings of the Royal Society of London, Series B-Biological Sciences 272:2251-2258.

HODKINSON, I.D. 2005. Adaptations of invertebrates to terrestrial Arctic environments. Transactions of the Royal Norwegian Society of Science and Letters 2:1-45.

HODKINSON, I.D., COULSON, S.J., WEBB, N.R., BLOCK, W., STRATHDEE, A.T., BALE, J.S., and WORLAND, M.R. 1996. Temperature and the biomass of flying midges (Diptera: Chironomidae) in the high Arctic. Oikos 75:241-248.

HODKINSON, I.D., WEBB, N.R., BALE, J.S., BLOCK, W., COULSON, S.J., and STRATHDEE, A.T. 1998. Global change and Arctic ecosystems: Conclusions and predictions from experiments with terrestrial invertebrates on Spitsbergen. Arctic and Alpine Research 30:306 -313.

HOLMES, R.T. 1966a. Breeding ecology and annual cycle adaptations of red-backed sandpiper (Calidris alpina) in northern Alaska. The Condor 68:3-7.

-1966b. Feeding ecology of red-backed sandpiper (Calidris alpina) in Arctic Alaska. Ecology 47:32-45.

HOLMES, R.T., and PITELKA, F.A. 1968. Food overlap among coexisting sandpipers on northern Alaskan tundra. Systematic Zoology 17:305-318.

HOLMGREN, N.M.A., JONSSON, P.E., and WENNERBERG, L. 2001. Geographical variation in the timing of breeding and moult in dunlin Calidris alpina on the Palearctic tundra. Polar Biology 24:369-377.

HURD, P.D., and PITELKA, F.A. 1954. The role of insects in the economy of certain Arctic Alaskan birds. In: Proceedings of the 3rd Alaskan Scientific Conference: Science in Alaska 1952. 22-27 September 1952, Mount McKinley National Park, Alaska. College, Alaska: Division of the American Association for the Advancement of Science. 136-137.

JONZEN, N., LINDEN, A., ERGON, T., KNUDSEN, E., VIK, J.O., RUBOLINI, D., PIACENTINI, D., BRINCH, C., SPINA, F., KARLSSON, L., STERVANDER, M., ANDERSSON, A., WALDENSTROM, J., LEHIKOINEN, A., EDVARDSEN, E., SOLVANG, R., and STENSETH, N.C. 2006. Rapid advance of spring arrival dates in long-distance migratory birds. Science 312:1959-1961.

KATTSOV, V. M., and KÄLLEN, E. 2005. Future climate change: Modelling and scenarios for the Arctic. In: Arctic climate impact assessment. Cambridge: Cambridge University Press. 99-150.

LACK, D. 1968. Ecological adaptations for breeding in birds. London: Methuen.

LEPAGE, D., GAUTHIER, G., and DESROCHERS, A. 1998. Larger clutch size increases fledging success and offspring quality in a precocial species. Journal of Animal Ecology 67: 210-216.
LINDHOLM, A., GAUTHIER, G., and DESROCHERS, A. 1994. Effects of hatch date and food supply on gosling growth in Arctic nesting greater snow geese. The Condor 96:898-908.

MacLEAN, S.F., and PITELKA, F.A. 1971. Seasonal patterns of abundance of tundra arthropods near Barrow. Arctic 24:19-40.

McBEAN, L. 2005. Arctic climate-past and present. In: Arctic climate impact assessment. Cambridge: Cambridge University Press. 21-60.

McCULLAGH, P., and NELDER, J.A. 1989. Generalized linear models, 2nd ed. London: Chapman and Hall.

MEEHL, G.A., WASHINGTON, W.M., COLlinS, W.D., ARBLASTER, J.M., HU, A.X., BUJA, L.E., STRAND, W.G., and TENG, H.Y. 2005. How much more global warming and sea level rise? Science 307:1769-1772.

MELTOFTE, H. 1985. Populations and breeding schedules of waders, Charadrii, in high Arctic Greenland. Bioscience 16: $1-43$.

MELTOFTE, H., HOYE, T.T., SCHMIDT, N.M., and FORCHHAMMER, M.C. 2007. Differences in food abundance cause inter-annual variation in the breeding phenology of High Arctic waders. Polar Biology 30:601-606.

MYERS, J.P., and PITELKA, F.A. 1979. Variations in summer temperature patterns near Barrow, Alaska-analysis and ecological interpretation. Arctic and Alpine Research 11: $131-144$.

PEARCE-HIGGINS, J.W., and YALDEN, D.W. 2004. Habitat selection, diet, arthropod availability and growth of a moorland wader: The ecology of European golden plover Pluvialis apricaria chicks. Ibis 146:335-346.

PIERSMA, T. 1997. Do global patterns of habitat use and migration strategies co-evolve with relative investments in immunocompetence due to spatial variation in parasite pressure? Oikos 80:623-631.

ROGERS, L.E., HINDS, W.T., and BUSCHBOM, R.L. 1976. General weight vs length relationship for insects. Annals of the Entomological Society of America 69:387-389.

ROGERS, L.E., BUSCHBOM, R.L., and WATSON, C.R. 1977. Length-weight relationships of shrub-steppe invertebrates. Annals of the Entomological Society of America 70:51-53.

SCHEKKERMAN, H. 1997. Graslandbeheer en groeimogelijkheden voor weidevogelkuikens. Report 292. Wageningen, The Netherlands: IBN-DLO [Institute for Forestry and Nature Research].

SCHEKKERMAN, H., VAN ROOMEN, M.W.J., and UNDERHILL, L.G. 1998. Growth, behaviour of broods and weather-related variation in breeding productivity of curlew sandpipers Calidris ferruginea. Ardea 86:153-168.

SCHEKKERMAN, H., TULP, I., PIERSMA, T., and VISSER, G.H. 2003. Mechanisms promoting higher growth rate in Arctic than in temperate shorebirds. Oecologia 134:332-342.

SCHEKKERMAN, H., TULP, I., CALF, K., and DE LEEUW, J.J. 2004. Studies on breeding shorebirds at Medusa Bay, Taimyr, in summer 2002. Report 922. Wageningen, The Netherlands: Alterra.

SEASTEDT, T.R., and MacLEAN, S.F. 1979. Territory size and composition in relation to resource abundance in Lapland longspurs breeding in Arctic Alaska. The Auk 96:131-142. 
SINCLAIR, B.J., ADDO-BEDIAKO, A., and CHOWN, S.L. 2003. Climatic variability and the evolution of insect freeze tolerance. Biological Reviews 78:181-195.

STONE, R.S., DUTTON, E.G., HARRIS, J.M., and LONGENECKER, D. 2002. Earlier spring snowmelt in northern Alaska as an indicator of climate change. Journal of Geophysical ResearchAtmospheres 107 (D10), doi:10.1029/2000JD000286, 2002.

TROY, D. 1996. Population dynamics of breeding shorebirds in Arctic Alaska. International Wader Studies 8:15-27.

TULP, I., and SCHEKKERMAN, H. 2001. Studies on breeding shorebirds at Medusa Bay, Taimyr, in summer 2001. Report 451. Wageningen, The Netherlands: Alterra.

TULP, I., SCHEKKERMAN, H., PIERSMA, T., JUKEMA, J., DE GOEIJ, P., and VAN DE KAM, J. 1998. Breeding waders at Cape Sterlegova, Northern Taimyr, in 1994. Working Group International Waterbird and Wetland Studies (WIWO), Report 61.
TURNOCK, W.J., and FIELDS, P.G. 2005. Winter climates and coldhardiness in terrestrial insects. European Journal of Entomology 102:561-576.

VISSER, M.E., and BOTH, C. 2005. Shifts in phenology due to global climate change: The need for a yardstick. Proceedings of the Royal Society of London, Series B-Biological Sciences 272:2561-2569.

VISSER, M.E., BOTH, C., and LAMBRECHTS, M.M. 2004. Global climate change leads to mistimed avian reproduction. Advances in Ecological Research 35:89-110.

WALSH, J.E. 2005. Cryosphere and hydrology. In: Arctic climate impact assessment. Cambridge: Cambridge University Press. $184-242$.

ZWARTS, L. 1990. Increased prey availability drives premigratory hyperphagia in whimbrels and allows them to leave the Banc d'Arguin, Mauritania, in spring. Ardea:279-300.

ZWARTS, L., and BLOMERT, A.M. 1990. Selectivity of whimbrels feeding on fiddler crabs explained by component specific digestibilities. Ardea 78:193-208. 